\title{
Georeferencing of cervical cancer in primary care
}

\author{
Georreferenciamento do câncer do colo do útero na atenção primária
}

José de Ribamar Ross ${ }^{1}$, Aliny de Oliveira Pedrosa² ${ }^{2}$ Nytale Lindsay Cardoso Portela ${ }^{3}$

Objective: to analyze the area distribution of cervical cancer screening. Methods: a cross-sectional study was carried out with 211 women, aged 38-69 years. The georeferencing technique was used to obtain geographic information, with coordinates of Global Positioning System. Results: of the 211 women, 93.8\% (198) underwent an oncotic cytology examination. Of these, $74.2 \%$ (147) were examined at irregular intervals. 16 cases of human papillomavirus with cervical oncotic cytology reports with Cervical Intraepithelial Neoplasia I, II and III were georeferenced. Conclusion: the area distribution of cervical cancer screening allowed the identification of coverage above the recommendations of the Brazilian Ministry of Health. In addition, in relation to the intervals between the cervical oncology cytology tests, the majority demonstrated execution at inappropriate intervals.

Descriptors: Uterine Cervical Neoplasms; Mass Screening; Health Centers.

Objetivo: analisara distribuição espacial do rastreamento do câncer do colo doútero. Métodos: estudo transversal, realizado com 211 mulheres, na faixa etária de 38 a 69 anos. Utilizou-se a técnica do georreferenciamento para obter informações geográficas, com coordenadas de Sistema de Posicionamento Global. Resultados: das 211 mulheres, 93,8\% (198) realizaram o exame de citologia oncótica. Destas, 74,2\% (147) procederam em intervalos irregulares. Foram georreferenciados 16 casos de papilomavírus humano com laudos de citologia oncótica cervical com Neoplasia Intraepitelial Cervical I, II e III. Conclusão: a distribuição espacial do rastreamento do câncer do colo do útero permitiu identificar cobertura acima das recomendações do Ministério da Saúde do Brasil. Ademais, em relação aos intervalos entre os exames de citologia oncótica cervical, a maioria demonstrou execução em intervalos inadequados.

Descritores: Neoplasias do Colo do Útero; Programas de Rastreamento; Centros de Saúde.

\footnotetext{
${ }^{1}$ Universidade Estadual do Maranhão. Caxias, MA, Brazil.

${ }^{2}$ Universidade Federal do Piauí. Teresina, PI, Brazil.

${ }^{3}$ Fundação Oswaldo Cruz. Rio de Janeiro, RJ, Brazil. 


\section{Introduction}

Cervical cancer is the most common cancer among women in 45 countries around the world and kills more than any other form of cancer in 55 countries, including many countries in sub-Saharan Africa, Asia (including India), and some countries in Central and South America. The large disparities in incidence and mortality among country-specific areas are related to socioeconomic and geographical variation, gender bias and cultural factors, which severely limit access to prevention services among some groups of women. In 2012, 528,000 new cases of cervical cancer were diagnosed worldwide, in which about $85.0 \%$ occurred in less developed regions ${ }^{(1)}$.

Cervical cancer is still one of the main public health problems faced by women, representing the second cause of death in Brazil, just behind breast and skin cancer (non-melanoma), not unlike the other underdeveloped countries. The number of new cases of this type of cancer in Brazil in 2013 was estimated at 17,540, with an estimated 17 cases per 100,000 wo$\operatorname{men}^{(2)}$. The estimated incidence for the year 2014 in Brazil was 15,590 cases of cervical cancer ${ }^{(3)}$.

In Brazil, the state of Maranhão is outstanding among other states every year, such as Piauí, Amazonas, Mato Grosso do Sul and Tocantins, in the high incidence and mortality rates of cervical cancer, even above the national average. Despite the high mortality rates, in the year 2014, 6.3\% (349) of the cities in Brazil did not present records of cervical oncology cytology examination ${ }^{(4)}$. In the period from 2006 to 2013, 59,155 cytological exams were performed in the city of Caxias, Maranhão, Brazil. In 2006, 10,780 tests were performed, of which 703 had positive results for cervical cancer, with a positive index of $1.1 \%{ }^{(5)}$.

Unlike the developed countries, in Brazil, there is no solid database of women's records, which makes it difficult to recruit them for observation and control of attendance for the specific exam. The existence of tools for the execution of the control of the intervals is fundamental for organization of the tracing. The number of exams offered by the Unified Health System is currently adequate for coverage purposes, however, it is observed that most women perform repeated exams and at intervals that are far from the recommendations recommended by the Ministry of Health.

Studies that monitor the coverage of cervical cancer screening are relevant to assess the return of activities undertaken, to check the periodicity, the interval of the examination practiced by women and the coverage reached by age group ${ }^{(6)}$. Thus, the use of geoprocessing and geo-referencing in health has become increasingly common. Geoprocessing uses mathematical and computational techniques to manipulate geographic information and one of the most used techniques is the Geographic Information System, a computerized resource that is used to capture, store, manage, analyze and present geographically referenced data ${ }^{(7)}$. Geo-referencing has geographic coordinates (latitude and longitude), involves computer technology, database and digital cartography and has been applied in health planning and monitoring(8).

Studies addressing the area distribution of diseases are of paramount importance for understanding the disease, predicting future cases, conducting the aetiological search, preventing and monitoring diseases, and evaluating the interventions performed in a given population ${ }^{(9)}$. In addition, the analysis of the spatial distribution allows to evaluate the need for decentralization of treatment and identifies the places with the greatest need for permanent education actions and the reallocation of human and physical resources, since it shows where the population is most affected $^{(10)}$.

The objective of this study was to analyze the spatial distribution of cervical cancer screening.

\section{Methods}

A cross-sectional study carried out in Caxirimbu, Caxias rural area, Maranhão, Brazil, from June to 
August 2015. In the Family Health Strategy unit of this locality, in 2014, there were 5,990 inhabitants registered, according to data provided by the coordination Primary Care. Of these, 3,014 corresponded to the female population, of which 465 were between 20 and 59 years old. In the period from March 2007 to July 2014, the health unit performed 1,028 cytopathological exams, according to records in the service control book.

The study population was composed of women accompanied by the family health unit of Caxirimbu. The following inclusion criteria were used: women with ages ranging from 25 to 64 years; have registered on the registration form by the community health agent; have lived in that area for at least three years. Women who had some cognitive impairment were excluded from the study.

In order to develop strategies to search for population screening for cervical cancer, a convenience sample was selected, by lot, according to the distribution in 10 micro areas of the rural area surveyed. In each micro-area, 21.1 women were interviewed on average. Based on this information, the sample size was 211 participants, for a $95 \%$ confidence level and a $5 \%$ margin of error.

Data collection was performed from Monday to Friday, during the morning shift, for a period of six months, at home, in a private area requested, according to the convenience of the woman selected and a previous appointment made by the community health agent of the microarea. Each interview lasted approximately 30 minutes.

A structured questionnaire was applied, containing questions related to the sociodemographic data of women, such as age, schooling, marital status, income, color; and screening tests.

In addition, to collect the geographical coordinates of each household, the Global Positioning System was used, which verified the contribution of the two groups formed, which had the paired data:
Group 1 (Women with Regular Cytology Examination) and Group 2 (Women with Irregular Cytology Examination).

The construction of the georeferencing maps was performed from the coordinates of the Global Positioning System, using the points of latitude and longitude collected from the 211 households visited. From this information, two maps were elaborated using the site http://www.garmin.com.br/br/mapas/, to identify the points. From the location of the coordinates in the Garmim site map, the mapping of the Caxirimbu locality was performed, then the overlap and the transfer of this information to the definitive Caxirimbu map were performed, with location points containing information on positive aspects and negatives. The black and gray points added corresponded to the quantitative of the absolute coverage frequencies reached.

After completing each micro-area, the questionnaires were cataloged in order to maintain a standard of organization. Then, the information contained in the questionnaires was transferred to a database and, subsequently, a descriptive analysis was performed in the Statistical Package for the Social Sciences, version 21.0 software.

The study respected the formal requirements contained in the national and international norms regulating research involving human beings.

\section{Results}

The women had an average age of 53.1 years ( $\mathrm{SD}=7.8$ years); $81.0 \%$ (171) lived with a spouse or partner; $78.0 \%$ (165) with incomplete grade school; $60.7 \%$ (128) had income less than a minimum wage; and $88.0 \%$ (185) were black and dark-skinned.

The interviewees who performed the most oncotic cytology examination were over 50 years old, married, with little schooling, income higher than two minimum wages and white. The interviewees who 
performed the least oncotic cytology were older than 50 years, widows, low schooling and black.

Figure 1 shows the cases of oncology cytology with Positive Cervical Intraepithelial Neoplasia, in which 16 cases of human papillomavirus were reported in reports of cervical oncotic cytology with Cervical Intraepithelial Neoplasia I, II and III.

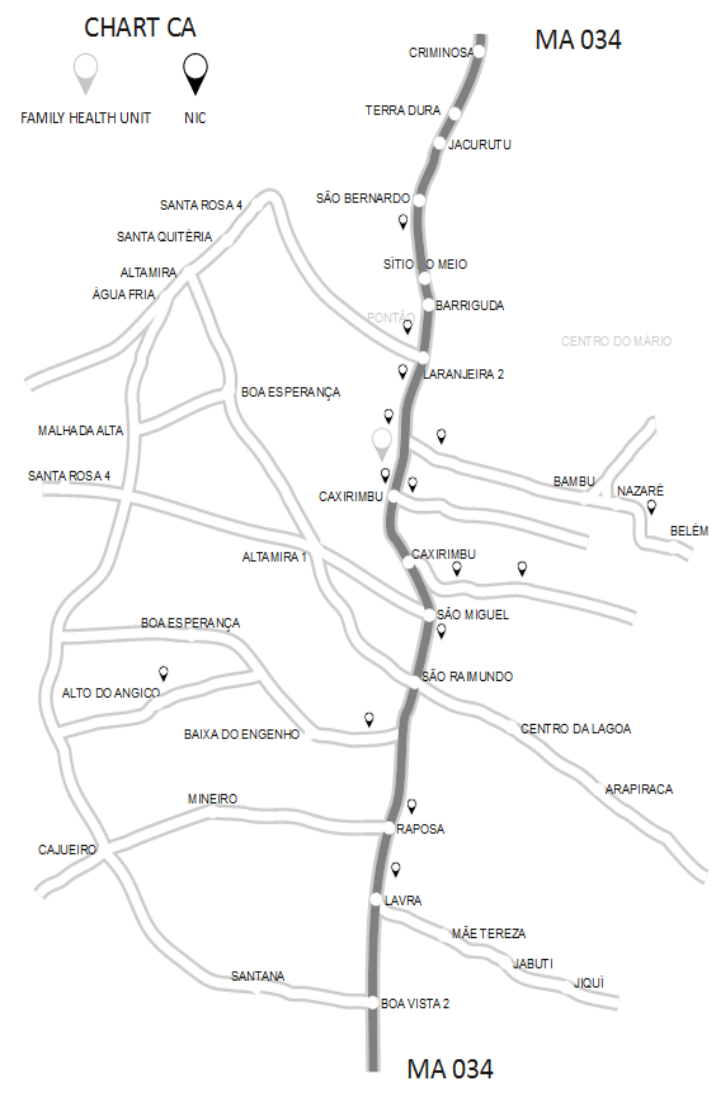

Figure 1 - Geographic distribution of the households of women who presented oncology cytology reports with Positive Cervical Intraepithelial Neoplasia

Figure 2 shows the location of women who did or did not undergo cervical oncology cytology. Of the 211 study participants, 198 (93.8\%) underwent the examination and 13 (6.2\%) reported never having made it.
The analysis of household georeferencing evidenced a high spatial distribution of cervical oncology cytology. This is possibly due to the fact that the site is close to the users' homes and the collection of the exam is performed in the daily routine, without bureaucracy and / or prior scheduling.

Figure 3 shows the geographical distribution of the households of women who performed cervical oncology cytology regularly and irregularly. Of the 198 women who had performed the Pap smear, $74.2 \%$ (147) performed irregularly, that is, distant from the standards determined by the Brazilian Ministry of Health, while $25.8 \%$ (51) had the screening regularly.

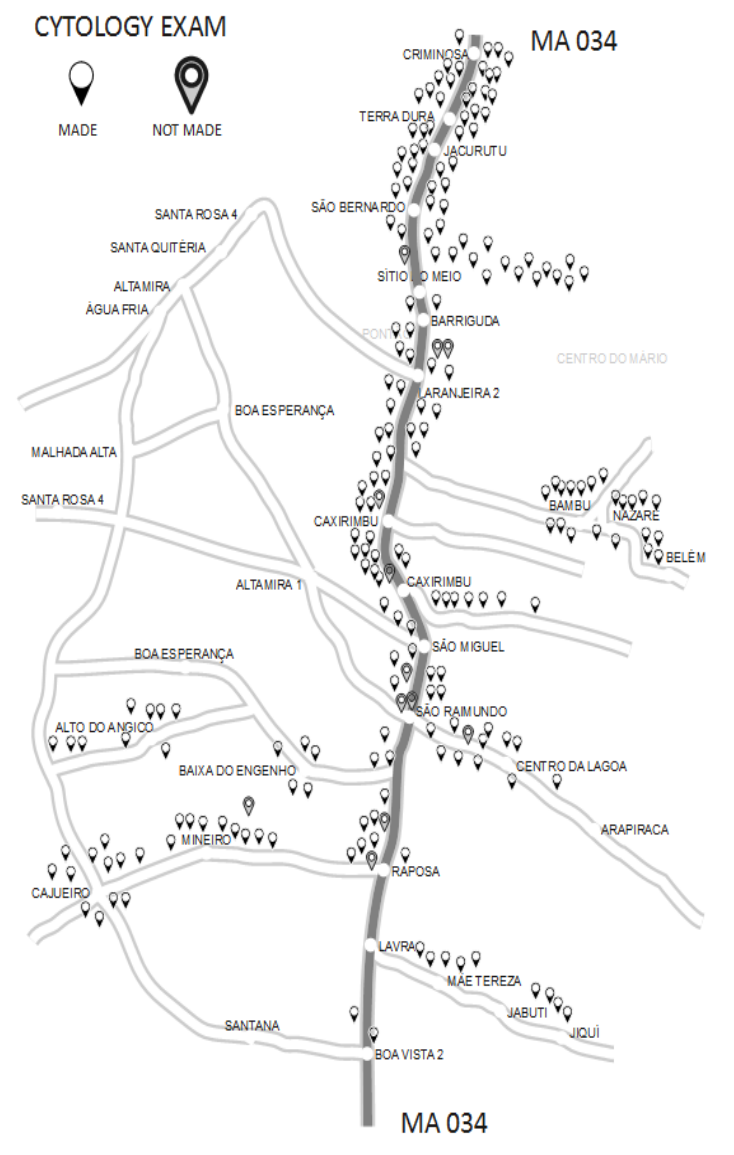

Figure 2 - Geographic distribution of visited households of women who did and did not undergo cytological examination 


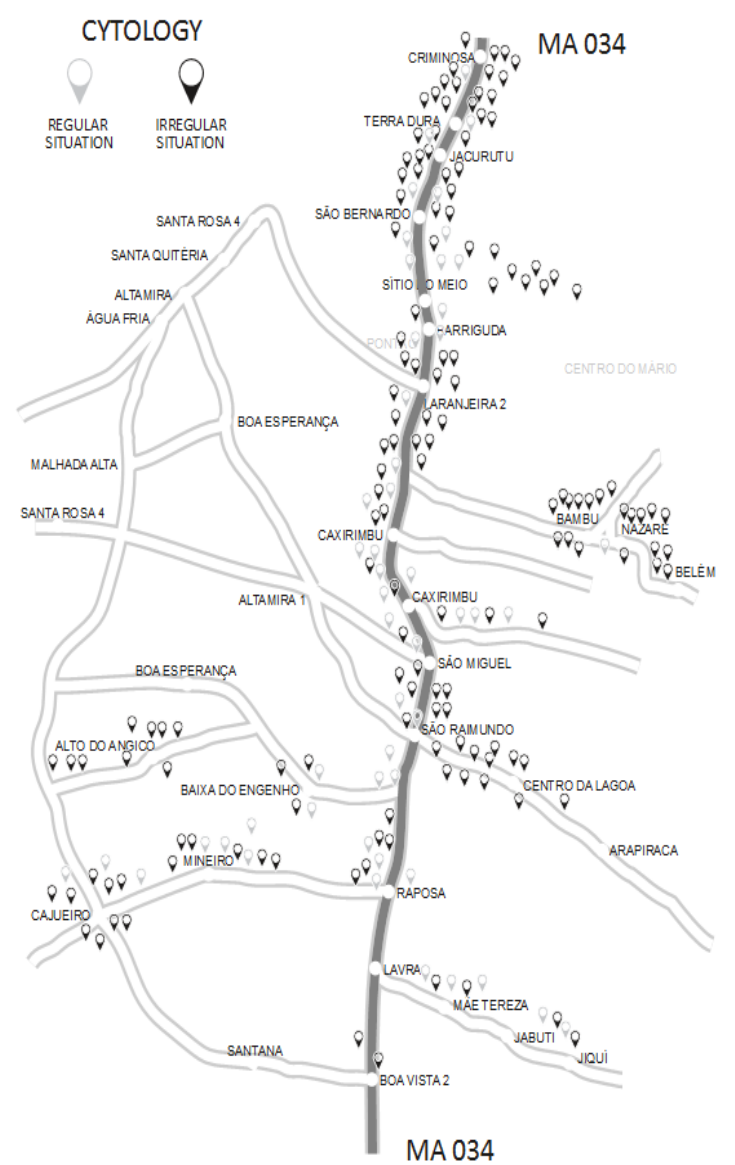

Figure 3 - Geographic distribution of visited households of women who underwent and cervical cytology regularly and irregular.

\section{Discussion}

The main limitations of this study were the quality of the information recorded in the service control book and possible memory bias of the participants, which influence the area distribution analysis.

In a similar study of 230 women aged 25-59, $31.5 \%$ (72) were in the $45-59$ age group, $63.0 \%$ (145) were married or lived in a stable union, $49.3 \%$ (112) had income less than or equal to a minimum wage and 87.6\% (197) declared themselves to be black/dark- -skinned, differentiating only the level of schooling, $42.6 \%$ (98) had finished high school ${ }^{(11)}$.

Of the 1,028 examinations carried out in the health care unit of this study, 1.6\% (16) presented Cervical Intraepithelial Neoplasia I, II and III. Similar results were found in a survey of 125,050 Pap smears collected in family health units in 2011, in which $0.9 \%$ $(1,129)$ had low grade, high grade or adenocarcinoma intraepithelial lesions ${ }^{(5)}$. Data from the Cervical Cancer Information System revealed that of the 71,872 examinations performed in the period 2007 to 2013, $0.7 \%$ (484) of the exams presented some lesion ${ }^{(12)}$.

The coverage of the exams, shown in this study, is above that expected by the Brazilian Ministry of Health, which advocates the examination of $80.0 \%$ of women in the 25 to 64 age group ${ }^{(2)}$, despite the low income and schooling of the population.

In another study carried out with a similar objective, there was a marked reduction in the number of tests for the target population of the uterine cervix cancer control program. There was also a high percentage of annual repetition of the exam, possibly related to the constant trend of percentage of unsatisfactory samples, in addition, low intake of women who had never performed the exam ${ }^{(13)}$, as evidenced in this study, in which $74.2 \%$ (147) of the women performed the exam in a time considered irregular by the Brazilian Ministry of Health.

The comparative survey between two Brazilian capitals showed a predominance of cervical oncocytic cytopathology made at one to two and one to three years spacing ${ }^{(14)}$. Such data were similar to those found in this study, since it showed that in both capitals women performed exams at shorter intervals than is recommended.

Other research corroborating the findings of this study shows that of the 2,059 women interviewed, $70.7 \%$ followed the recommendations of the Ministry of Health on screening for cervical cancer ${ }^{(15)}$. 
Brazil has lack of research with this methodology. Thus, this study contributes to the development of national policies, especially to populations similar to the citizens of the locality studied. In addition, it shows the need to optimize the form of registration of the exams, a reality common in other locations, in order to provide a solid base of information on the tracking for the health team and the organized recruitment of women.

\section{Conclusion}

The area distribution of cervical cancer screening made it possible to identify coverage above the recommendations of the Brazilian Ministry of Health. In addition, in relation to the intervals between the cervical oncology cytology tests, the majority demonstrated execution at inappropriate intervals.

\section{Collaborations}

Ross JR contributed in project and design. Pedrosa AO and Portela NLC contributed to the analysis and interpretation of the data, writing of the article, critical review of the intellectual content and final approval of the version to be published.

\section{References}

1. World Health Organization. Comprehensive cervical cancer control: a guide to essential practice. Geneva: WHO; 2014.

2. Ministério da Saúde (BR). Secretaria de Atenção à Saúde. Departamento de Atenção Básica. Controle dos cânceres do colo do útero e da mama. Brasília: Ministério da Saúde; 2013.

3. Instituto Nacional de Câncer (BR). Coordenação de Prevenção e Vigilância. Estimativa 2014: Incidência de Câncer no Brasil. Rio de Janeiro: INCA; 2014.
4. Instituto Nacional do Câncer (BR). Informativo detecção precoce. Monitoramento das ações de controle do câncer do colo do útero - Linha de cuidado e Rede de Atenção ao câncer do colo do útero. Rio de Janeiro: INCA; 2015.

5. Silva DSM, Silva AMN, Brito LMO, Sinara RLG, Nascimento MDSB, Chein MBCC. Rastreamento do câncer do colo do útero no Estado do Maranhão, Brasil. Ciên Saúde Coletiva. 2014; 19(4):1163-70. http://dx.doi.org/10.1590/141381232014194.00372013

6. Ministério da Saúde (BR). Informações Estatísticas (Versão 4.0): Exame Citopatológico Cérvico-Vaginal e Microflora - Maranhão. Brasília: Ministério da Saúde; 2015.

7. Portz L, Rockett GC, Franchini RAL, Manzolli RP, Gruber NLS. Gestão de dunas costeiras: o uso de sistema de informações geográficas (SIG) na implantação de planos de gestão no litoral do Rio Grande do Sul, Brasil. Rev Gestão Cost Integ. 2014; 14(3):517-34. http://dx.doi.org/10.5894/ rgci 445

8. Mendes RV, Coelho LS, Macêdo PF, Souza TBP, Santos TFC, Gaião L. Distribuição espacial e geoprocessamento de pacientes com fissura labiopalatina na cidade de Imperatriz, Maranhão, Brasil. Rev Bras Ciên Saúde. 2015; 19(4):261-8. http://dx.doi.org/10.4034/RBCS.2015.19.04.02

9. Cavicchioli Neto V, Chiari NS, Carvalho I, Pisa IT, Alves D. Desenvolvimento e integração de mapas dinâmicos georreferenciados para o gerenciamento e vigilância em saúde. J Health Inform [Internet]. 2014 [citado 2017 jun. 30]; 6(1):3-9. Disponível em: http://www.jhi-sbis. saude.ws/ojs-jhi/index.php/jhi-sbis/article/ view/284/185.

10. Nardi SMT, Paschoal JAA, Pedro HSP, Paschoal VD, Sichieri EP. Geoprocessamento em saúde pública: fundamentos e aplicações. Rev Inst Adolfo Lutz [Internet]. 2013 [citado 2017 jun. 30]; 72(3):18591. Disponível em: http://revistas.bvs-vet.org.br/ rialutz/article/view/22284/23728 
11. Andrade MS, Almeida MMG, Araújo TM, Santos KOB. Fatores associados à não adesão ao Papanicolau entre mulheres atendidas pela Estratégia Saúde da Família em Feira de Santana, Bahia, 2010. Epidemiol Serv Saúde. 2014; 23(1):111-20. http://dx.doi.org/10.5123/S167949742014000100011.

12. Rodrigues JF, Moreira BA, Alves TGS, Guimarães EAA. Rastreamento do câncer do colo do útero na região ampliada oeste Minas Gerais, Brasil. R Enferm Centr O Min. 2016; 6(2):2156-68. http:// dx.doi.org/ 10.19175/recom.v6i2.1075

13. Damacena AM, Luz LL, Mattos IE. Cervical cancer screening in Teresina, Piauí, Brazil: evaluation study using data of the Cervical Cancer Information System, 2006-2013. Epidemiol Serv Saúde. 2017; 26(1):71-80. http://dx.doi.org/10.5123/s167949742017000100008
14. Barboza BMS, Zeferino LCZ. Por que a prevalência de resultados citopatológicos do rastreamento do câncer do colo do útero pode variar significativamente entre duas regiões do Brasil? Rev Bras Ginecol Obstet. 2014; 36(5):192-7. http://dx.doi.org/10.1590/S01007203201400050003

15. Girianelli VR, Thuler LCS, Silva GA. Adesão ao rastreamento para câncer do colo do útero entre mulheres de comunidades assistidas pela Estratégia Saúde da Família da Baixada Fluminense, Rio de Janeiro, Brasil. Rev Bras Ginecol Obstet. 2014; 36(5):198-204. http:// dx.doi.org/10.1590/S0100-7203201400050003 